
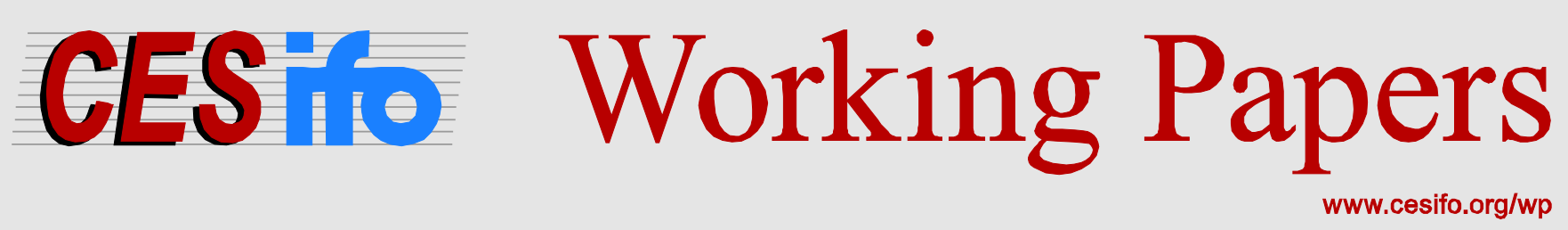

\title{
Love your Leave, Don't Leave your Love! Paid Parental Leave and Children's Living Arrangements
}

\author{
Kamila Cygan-Rehm \\ Daniel Kühnle \\ Regina T. Riphahn
}

CESIFO WORKING PAPER NO. 6319

CATEGORY 3: SOCIAL PROTECTION

JANUARY 2017

An electronic version of the paper may be downloaded

- from the SSRN website:

- from the RePEc website:

- from the CESifo website:

WwW.SSRN.com

www.RePEc.org

www.CESifo-group.org/wp 


\title{
Love your Leave, Don’t Leave your Love! Paid Parental Leave and Children's Living Arrangements
}

\begin{abstract}
We examine how a German paid parental leave reform causally affected early childhood living arrangements. The reform replaced a means-tested benefit with a universal transfer paid out for a shorter period. Using a difference-in-differences design, we find that the reform increased the probability that a newborn lives with non-married cohabiting parents. This effect results from a reduced risk of single parenthood among women who gained from the reform. We reject the economic independence hypothesis and argue that the effects for reform winners are consistent with alternative hypotheses related to increased female financial attractiveness and increased paternal involvement in childcare.
\end{abstract}

JEL-Codes: J120, J130, J180, I300.

Keywords: parental leave, living arrangements, marriage, cohabitation, single motherhood, child well-being, early childhood.

\author{
Kamila Cygan-Rehm \\ Friedrich-Alexander University \\ FAU Erlangen-Nürnberg \\ Economics Department \\ Lange Gasse 20 \\ Germany - 90403 Nürnberg \\ kamila.cygan-rehm@wiso.uni-erlangen.de
}

\author{
Daniel Kühnle \\ Friedrich-Alexander University \\ FAU Erlangen-Nürnberg \\ Economics Department \\ Lange Gasse 20 \\ Germany - 90403 Nürnberg \\ daniel.kuehnle@fau.de
}

\author{
Regina T. Riphahn* \\ Friedrich-Alexander University \\ FAU Erlangen-Nürnberg \\ Economics Department \\ Lange Gasse 20 \\ Germany-90403 Nürnberg \\ regina.riphahn@fau.de
}

*corresponding author

January 12, 2017

We thank participants of the Leopoldina Section 25 meeting (Mannheim), the DFG Priority program (SPP 1764) workshop in Nürnberg, the CESifo Area Conference on Employment and Social Protection, the ESPE meeting in Izmir, the EEA meeting in Mannheim, the department seminars in Würzburg, Potsdam, and Bayreuth, the Labour and Public Policy Seminar at Aarhus University, the economic department seminar at the University of Melbourne, the Life Course Centre Seminar at the University of Sydney, and the seminar series at ZEW in Mannheim and SFI in Copenhagen for helpful comments. This work was supported by the German Research Foundation (Deutsche Forschungsgemeinschaft) grant number RI 856/7-1 and the Hans-Frisch-Stiftung grant number 15/12. 


\section{INTRODUCTION}

An extensive literature documents significant relationships between children's living arrangements and general wellbeing. Specifically, children raised by single mothers have worse educational, labor market, and mental health outcomes compared to children living with both biological parents (McLanahan and Sandefur 1994). Analyses with more rigorous research designs (e.g., Painter and Levine 2000, Lang and Zagorsky 2001, Finlay and Neumark 2010, McLanahan, Tach, and Schneider 2013) usually yield smaller adverse effects of fragile family structure and fathers' absence than earlier cross-sectional studies. Nevertheless, Blau and van der Klaauw (2013, p. 579) argue that the differences in outcomes between children from different family structures "are generally quite large and dwarf the effects of income and maternal employment". Therefore, early childhood living arrangements may be a central source of inequality and have potentially long lasting consequences for children. These issues are particularly important given the trend of the past 50 years towards more alternative living arrangements (Lundberg, Pollack, and Stearns 2016).

Despite the robust relationship between living arrangements and children's outcomes, we still know little about how public policy affects children's living arrangements. So far, the literature on the intended and unintended effects of welfare reforms on living arrangements is dominated by research on US programs such as the Temporary Assistance for Needy Families (TANF) or the Earned Income Tax Credit (EITC) (e.g., Dickert-Conlin and Houser 2002; Bitler, Gelbach, Hoynes, and Zavodny 2004; Bitler, Gelbach, and Hoynes 2006; Fitzgerald and Ribar 2004; Blank 2002; Grogger and Karoly 2005; Ratcliff, McKernan, and Rosenberg 2002; or Hu 2003). ${ }^{1}$ Most studies examine the effects on the marital and cohabitation status of women using US data and focus on the bottom tail of the income distribution. The results are, however, mixed (see also Ellwood 2000; Schoeni and Blank 2000; Cancian and Meyer 2014).

1 An exception is the study by Gregg, Harkness, and Smith (2009) who investigate effects of UK welfare reforms on a broad range of outcomes for lone mothers. 
Only a few studies examine the effects of these programs on children's living arrangements directly. For instance, Acs and Nelson (2004) investigate the effect of specific elements of TANF on children's and women's living arrangements. While their findings are mixed, some evidence shows that family caps increase the probability of children living with their parents, and that child-support enforcement measures reduce the incidence of single parenthood. Bitler et al. (2006) show that the US welfare reform of 1996 reduced the probability of living with an unmarried parent. In contrast, Blau and van der Klaauw (2013) examine various determinants of family structure and conclude that welfare benefits have rather small effects compared to the substantial effects of wage rates and tax incentives. Overall, the literature found mixed effects of welfare reforms on living arrangements, focused almost exclusively on the US, and has not examined the effects of other public policy programs.

The purpose of our paper is to address these gaps by examining the effect of a paid parental leave reform in Germany on children's living arrangements. The reform replaced a means-tested benefit with a more generous universal transfer that was paid out for a shorter period. We contribute to the literature on the link between public policies and children's living arrangements in several ways. First, while most previous studies draw on samples of single mothers and welfare recipients, we examine a universal reform that affected all families across the income distribution. Given that the reform generated winners and losers, we pay particular attention to potentially heterogeneous effects. Second, we consider various mechanisms through which the reform might affect living arrangements such as changes in economic independence, spousal bargaining powers, female financial attractiveness, new incentives for fathers to be more involved in child rearing, and marriage disincentives deriving from the German income tax code. Third, by investigating the potentially different effects for girls and boys, we contribute to the literature on the link between paternal preferences for a child's gender and living arrangements (e.g., Dahl and Moretti 2008). Fourth, unlike most of the previous literature, we examine children's outcomes and thus study the direct effects on early childhood 
living arrangements. Finally, we provide evidence for a country outside the US and thus for a different institutional and cultural setting.

To identify the causal effect of changes in parental leave benefits on children's living arrangements, we apply a difference-in-differences design. Using data from the German Micro Census, we find that the reform increased the probability that a newborn child lives with cohabiting parents, and that the positive effect persists beyond the benefit take-up period. This effect is mainly driven by a reduced risk of growing up with a single mother, and does not result from a shift away from marital unions. Our estimates reject the economic independence hypothesis and are consistent with alternative hypotheses related to increased female financial attractiveness and increased paternal involvement in childcare. Finally, boys and girls are affected differently: after the reform, daughters are more likely to live with their fathers, whereas the living arrangements of boys remain unchanged. This reduces a prior disadvantage of daughters who were significantly more likely to live with single mothers than sons.

The paper proceeds as follows. Section 2 provides information about the parental leave reform and related literature. Section 3 illustrates the mechanisms through which the reform might affect children's living arrangements. Section 4 describes the data and our empirical approach. Section 5 discusses our key estimation results and shows that they pass numerous sensitivity checks. Section 6 concludes that the German paid parental leave reform generated unintended, yet important, effects for children's living arrangements.

\section{INSTITUTIONS}

The German family policy includes three relevant programs aiming at the wellbeing of parents and newborns: first, maternity leave and maternity benefits are available from six weeks before to eight weeks after childbirth. Second, parents can take parental leave which provides job protection for up to three years after birth (cf. Dustmann and Schönberg 2012). 
Third, parents are entitled to parental leave benefits. This program substantially changed in 2007. Prior to the reform, child-rearing benefits (Erziehungsgeld) were means-tested and paid a maximum of 300 Euro per month for up to 24 months. ${ }^{2}$ The eligibility criteria of the means test related to the family income: parents were eligible for full child-rearing benefits if their annual net income was below a threshold. ${ }^{3}$ The benefits were exempted from income taxation.

Parents of children born after the reform became effective on January 1, 2007 are newly entitled to "parents' money" (Elterngeld). This program had three main objectives: to financially support young families, to strengthen mothers' employment incentives after birth, and to enhance paternal involvement in child care. The new benefit generally amounts to two thirds of average net earnings in the 12 months prior to childbirth for the parent who reduces employment after birth. Parents employed part-time after childbirth receive a transfer of 300 Euro per month as a minimum and additionally up to two thirds of the drop in earnings if a reduction in hours worked occurred after the birth. The minimum benefit of 300 Euros per month is available also for those previously not employed. The maximum Elterngeld transfer is capped at 1,800 Euro per month. Similar to the previous child-rearing benefits, parents' money is not subject to income tax. However, the new benefit is considered for the calculation of the applicable tax rate in the progressive tax system and thus causes an increase in tax rates for taxable income (progressivity effect, Progressionsvorbehalt). ${ }^{4}$

2 The payout over 24 months is called the regular benefit version. Alternatively, parents could choose a payout of 450 Euro per month for 12 months, called the budget version. As only a minority of about 13 percent used the budget version, our description focuses on the regular benefit version.

3 If net income exceeded the threshold, payouts were reduced. These thresholds differed for couples and single parents and varied with the number of children in the household. They also differed for benefits to be paid in months 1-6 vs. 7-24 after a birth.

$4 \quad$ LaLumia et al. (2015) discuss that the lack of pro-rated income tax deductions has distorting effects for the timing of births in the United Status. This phenomenon does not exist in Germany as fertility related tax deductibles are pro-rated. 
One parent can receive the benefit for up to 12 months and the other parent for additional two months ("daddy-months") if both live in one household with the child and if they personally care for the child. The "daddy-months" regulation was introduced to incentivize paternal involvement in child rearing and to support the return of mothers to the labor force one year after birth. Parents are free to split the total of 14 months of benefits between themselves; a single parent is eligible for 14 months. ${ }^{5}$

Administrative statistics (see, e.g., STBA 2012) indicate that the share of fathers utilizing paid parental leave jumped from about 3.5 percent before the reform to 15 percent in 2007, the first post-reform year. After the reform, 13 percent of fathers and 2 percent of mothers who utilize paid parental leave in the first year received the maximum amount of 1.800 Euro (STBA 2008). Figure 1 shows that the share of father's taking up the new benefit increased continuously over time and reached 32.3 percent for births of 2013 (STBA 2015a). Geisler and Kreyenfeld (2012) point out that after the reform, leave taking increased the most among highly educated fathers. While the average duration of mothers' transfer receipt remained constant at around 11.7 months, the average duration of fathers' transfer receipt fell from 4.2 months for births in 2007 to 3.1 months for births in 2013 (STBA 2015b) conditional on benefit receipt. ${ }^{6}$

Compared to the prior means-tested benefit (Erziehungsgeld), the new Elterngeld benefit is more generous in terms of transfer amounts and less generous in terms of transfer durations, as it runs for only 12 (or 14) as opposed to 24 months before the reform given eligibility. The reform thus generated "losers" among lower income parents who lost 12 months of transfers after the reform, i.e., up to 3,600 Euro. It generated "winners" among higher income

$5 \quad$ Parents can double the transfer period of the new Elterngeld benefit if the monthly benefit is halved. Only about ten percent of recipients use this option (STBA 2013).

6 The share of fathers receiving benefits no longer than 2 months increased from 65.3 to 78.9 percent between 2007 and 2013. The share of mothers receiving benefits for 10-12 months increased in the same period from 86.6 to 92.4 percent (see STBA 2008 and 2015b). Jointly these numbers might suggest the development of a new social norm where fathers take parental leave for two months. 
parents who newly receive a generous transfer of up to 21,600 Euro. In relative terms, the reform's losers lost at least 22 percent of their net household income since only those with an income of less than 16,500 Euro received the maximum benefit amount prior to the reform. The relative gain for winners reached 33 percent of net household income: only double-earner households with net annual incomes of at least 64,800 Euro (i.e. 2,700 Euro monthly per parent) receive the maximum benefit amount. Clearly, behavioral responses to the reform may differ between the two groups.

Three prior studies have examined the reform's effects on related issues: Geisler and Kreyenfeld (2012) find a significant increase in fathers' propensity to take parental leave after the reform. Using a non-representative survey, Kluve and Tamm (2013) consider fathers' share in total childcare in the first year after a birth and find no significant reform effects. Finally, Kluve and Schmitz (2014) study numerous outcomes, including the probability of being married for different subsamples of mothers. They find significant reductions in marriage rates through year five after childbirth and explain this finding with the reduced tax incentives for married couples after the reform. So far, the reform effect on child living arrangements remains unaddressed.

\section{MECHANISMS AND HYPOTHESES}

The German paid parental leave reform of 2007 substantially changed the incentives for parents to take parental leave. Thus, the reform affected parental income, employment, child care, and potentially even fertility. In this section, we draw from economic models of the family (Becker, 1991; Browning, Chiappiori, and Weiss 2014) to illustrate the pathways through which the parental leave reform might affect children's living arrangements.

First, the new parental leave benefit affected the disposable income of the parent taking parental leave. Thus, parental leave might affect living arrangements through changes in income, where theory predicts ambiguous effects. For instance, the economic independence 
hypothesis (Cancian and Meyer 2014) posits that additional income makes a woman more independent, reducing the need to pool resources, and thus increasing the probability of single motherhood. On the other hand, an increase in income raises the relative financial attractiveness of a woman or relax the household budget constraint leading to an increase in household welfare and lower financial stress. These mechanisms then may reduce the risk of single motherhood.

From the perspective of collective bargaining models (Lundberg and Pollak 1996, 2007), an increase in income raises women's bargaining power generally, and specifically, the "divorce threat point" (Manser and Brown 1980), i.e., the relative well-being outside of marriage. The overall effect of changing bargaining power is ambiguous. Changing divorce threat points may increase the probability of single motherhood if the expected utility outside of a current relationship is higher than the expected utility from the current union. However, instead of separation, women may also use the increase in relative bargaining power to negotiate more favorable terms concerning the private consumption by spouses, time spent with or resources spent on children, or the division of household labor, cooperatively within the existing partnership (Lundberg and Pollack 2007). If, for instance, women negotiate more paternal involvement in child rearing, fathers' investments in their children increase. Similarly, mothers may use the extra resources to invest more in their children, and particularly their daughters (Lundberg, Pollak and Wales 1997). Such investments may increase the consumption value of children for both parents and improve union stability.

Overall, the predictions for the effect of additional disposable income on household structure are ambiguous. Moreover, in case of the German reform, we observe both winners with additional and losers with reduced transfers. The mechanisms discussed above hold for both groups and may cause higher and lower risks of single motherhood for either group.

Second, the reform affected the return-to-work incentives during the first two years after childbirth. Overall, hours worked are adjusted in different ways during and after benefit receipt by both those who gained and those how lost out after the reform (Bergemann and Riphahn 
2015). These changes in maternal employment can affect living arrangements in various ways. For example, if women substitute employment with child care activities, this may be considered an investment in relationship-specific public goods and strengthen union stability (Becker 1991). In contrast, findings by Brooks-Gunn, Han, and Waldfogel (2002) indicate that an early return-to-work may negatively impact the mother-child attachment, increasing the risk of emotional problems for both mother and child, leading to a higher risk of single motherhood. Thus, the overall effect again depends on the relative effect sizes of such mechanisms.

Third, the reform generates incentives for fathers to increase their paternal leave taking through higher wage replacements and by the introduction of two "daddy months". ${ }^{7}$ We expect higher paternal leave taking to positively affect union stability. If the reform increases paternal involvement in childcare, fathers are likely to invest more time in their children which should decrease the risk of single motherhood. This mechanism is consistent with the father involvement hypothesis (Morgan, Lye, and Condran 1988) which suggests that parents have a lower risk of separation if fathers are more involved in child rearing processes due to greater family bonding. In addition, if both parents take parental leave at the same time, both spouses can enjoy consumption complementarities in leisure and child care activities. Therefore, higher paternal involvement should increase the relative value of the relationship and thus reduce the risk of single motherhood. However, low-income families may not be able to afford the income reduction implied by a father taking up leave, particularly if the father is the only income earner. Indeed, Reich (2011) shows that after the reform, the fathers' leave taking positively correlates with the maternal employment and income. Therefore, we expect a decline in single parenthood

\footnotetext{
7 Some recent studies examine the effects of "daddy months". For instance, Cools, Fiva, and Kirkebøen (2015) examine how a Norwegian paternal leave quote affected child and family outcomes; Ekberg, Eriksson, and Friebel (2013) study the household behavior and labor market effects of a Swedish reform; and Rege and Solli (2013) investigate the effect of paternity leave on fathers' long-term earnings.
} 
particularly among families where the father is not the only income earner, i.e., for mothers with own labor income who represent the winners of the reform.

Fourth, the reform may generate differential effects for boys and girls. Several studies suggest that fathers may have a preference for sons. Therefore, a child's gender may affect marital stability and married parents with sons exhibit greater marital satisfaction than families with only daughters (see, e.g., Morgan, Lye, and Condran 1988). Dahl and Moretti (2008) for the US and Choi et al. (2008) for West Germany show that sons are more likely to live with their fathers than daughters. ${ }^{8}$ Hence we expect greater involvement effects for sons and stronger effects on living arrangements for boys.

Fifth, the parental leave reform tightened the time limit for low-income women as the new benefit can only be received for 12 as opposed to 24 months previously. The US literature (e.g., Dunifon, Hynes, and Peters 2009) has shown that welfare reforms imposing stricter time limits may affect living arrangements by increasing the incentive to partner up to insure against future income losses. Hence, we expect that stricter time limits reduce the probability of living with a single mother for children whose mothers' entitlement period was reduced, i.e., the losers of the reform.

Sixth, the reform generated a marriage disincentive that is strongest for individuals at the bottom of the income distribution. The reason is fairly intuitive. The German income tax system uses a progressive tax function (see Figure 2) and provides a tax incentive for marriage. ${ }^{9}$ The new parental leave benefit shifts the tax schedule of married couples towards higher tax

$8 \quad$ However, Diekmann and Schmidheiny (2004) do not confirm these findings. They analyze data from 18 different countries and do not find that having a girl increases the risk of divorce.

9 The German income tax system applies a tax splitting rule for married couples based on the joint income: if $\mathrm{y}_{M}$ and $\mathrm{y}_{\mathrm{F}}$ are incomes of male and female spouses and $\mathrm{y}_{\mathrm{C}}$ is the total income of the married couple, then a progressive tax function $\mathrm{T}($.$) yields that 2 * \mathrm{~T}\left(0.5 * \mathrm{yc}_{\mathrm{C}}\right) \leq \mathrm{T}\left(\mathrm{y}_{\mathrm{M}}\right)+$ $\mathrm{T}(\mathrm{yF})$. Thus, for most couples, this generates a tax benefit of being married. This tax splitting advantage is largest for couples where one spouse earns the total income. 
rates (progressivity effect). ${ }^{10}$ The effective tax rate is then applied to total household income. Thus, the new leave benefit contributes to an increase in average taxes which is particularly pronounced for low income households (see Table A.1). We therefore expect that the progressivity effect reduces the propensity to marry for individuals with low incomes for the period of benefit receipt.

Taken together, this discussion shows that the overall reform effect will depend on the relative sizes of these, at times opposing, effects. Moreover, the effect is likely to vary between women who gained and lost out from the reform. Ultimately, the effect of the reform on living arrangements is an empirical question.

\section{METHODS AND DATA}

\subsection{EMPIRICAL STRATEGY}

To identify the causal effect of the reform, we compare outcomes of children born shortly before and shortly after the reform came into effect. Given that we only have information on a child's month of birth, we consider a window of three months around the cut-off date January 1, 2007 to maximize precision while reducing the risk of potential confounders. Furthermore, parents of children born after March 2007 could already have known about the reform at the time of conception. To isolate possible seasonal effects from those of the policy change, we include children born in exactly the same months but in two pre-reform years (2004/05 and 2005/06) and two post-reform years (2007/08 and 2008/09) as a control group. This strategy uses the

10 Importantly, unlike many of the US welfare programs, being married is not a precondition for receiving the parental leave benefit (Cancian and Meyer 2014). Similarly, work requirements and financial sanctions, which feature in many US welfare reforms and which can have direct effects on living arrangements, do not exist in the German paid parental leave program. 
sharp cut-off date of the reform's introduction to assign the treatment status within a differencein-differences approach. ${ }^{11}$ We estimate a linear model of the form:

$$
\mathrm{y}_{i}=\text { const }+\alpha \text { treat }_{\mathrm{i}}+\beta \text { after }_{\mathrm{i}}+\gamma\left(\text { treat }_{\mathrm{i}} \cdot \text { after }_{\mathrm{i}}\right)+\text { cohort }_{\mathrm{i}}^{\prime} \theta+\mathrm{x}_{\mathrm{i}}^{\prime} \delta+\varepsilon_{i}
$$

where $y_{i}$ denotes the living arrangement for a child i. We study three mutually exclusive outcomes: living with a married couple, a cohabiting couple, and a single mother. ${ }^{12}$ The indicator variable treat $_{i}$ equals one if a child belongs to the treated birth cohort, i.e., was born around the reform's cut-off date. ${ }^{13}$ We define a cohort as children born from October through the next March, so that the treated cohort 2006/07 comprises children born in the last quarter of 2006 and in the first quarter of 2007. Seasonal effects are captured by the variable after which corresponds to an indicator for being born in the first quarter of a year versus the last quarter of the previous year. The vector cohort $_{i}$ includes a set of indicator variables that are equal to one if a child belongs to a particular non-treated birth cohort. cohort $_{i}$ comprises three indicator variables, the reference cohort is 2004/05.

Additionally, $x_{i}$ covers a child's demographic characteristics such as its age in months (linear and squared), gender, an indicator for multiple births, and state of residence. We also control for maternal socio-demographic characteristics measured prior to childbirth such as her age in years (linear and squared), education, employment, and migration status. The terms $\alpha$, $\beta, \gamma, \theta$, and $\delta$ represent coefficients to be estimated, and $\varepsilon_{i}$ is a random error term.

11 Dustmann and Schönberg (2012) use a similar strategy to evaluate expansions in maternity leave duration on children's long-term outcomes. We follow these authors and apply linear regression models to facilitate the interpretation of interaction term effects (Ai and Norton 2003).

12 Given that in Germany a mother's absence at early stages of baby's life is very rare, we do not consider single fatherhood. We exclude roughly 0.3 percent of children who live without the mother from our sample. In addition, it would be interesting to study actual switches in living arrangements. Unfortunately our data does not provide information on the dynamics of the outcome variables.

13 We identify intention to treat (ITT) effects. About 96 percent of all families took up the new benefit, however, we cannot identify them in our data (STBA 2012). 
The key assumption to identify the coefficient of interest, $\gamma$, is that a child's birth date was not affected by the reform's introduction. A major validity threat is that parents would have known about the reform at the time of conception. However, Kluve and Tamm (2013) show that the public discussion started in May 2006 when the governing parties agreed on the cornerstones of the reform. Parliament passed the new benefit in September 2006 and until then it was not clear whether the reform would eventually take place. This timeline and the fact that parents cannot perfectly plan the conception of a child provide convincing evidence that births in the first quarter of 2007 were still independent of the reform.

The identification strategy would also fail if mothers could have influenced a child's birth date by bringing the delivery forward or backward. Indeed, there is evidence showing that a significant number of women postponed December births to January to become eligible for the new benefit (Neugart and Ohlsson 2012, Tamm 2012). However, because less than 8 percent of mothers with due dates in the last December week successfully postponed delivery (Tamm 2012), the presence of such timing should be of minor importance for our results. Nevertheless, we assess the sensitivity of the results to the exclusion of births around the cut-off day of the reform.

\subsection{DATA}

We use data from the German Micro Census 2005-2012. Each survey year provides a one percent cross-section of the population currently living in Germany (for details see, e.g., STBA 2016). The key advantages of the Micro Census are the availability of information on an individual's month of birth and relatively large sample sizes. We restrict the sample to children born in Germany and belonging to the birth cohorts 2004/05 through 2008/09. We match a child to its parents if they live in the same household at the time of the interview. We further restrict the sample to first-born children as the time around first birth is typically associated with the highest relative risk of marriage and union formation (see Köppen 2011). Also, we focus on 
children who reside in West Germany for three main reasons: first, they represent the vast majority ( 80 percent) of the population of interest; second, West and East Germany differ in many aspects related to living arrangements in early childhood. ${ }^{14}$ Finally, while a separate analysis of the East German case is of interest, our East German sample is too small for an informative investigation.

We observe the outcomes of analyzed cohorts of children at different ages in different Micro Census waves. For example, Micro Census 2007 reports the living arrangements of the treated cohort 2006/07 in their first year of life and Micro Census 2008 in their second year of life. Table 1 illustrates the relationship between age of the included cohorts and the reporting year and provides the number of observations, as well. We estimate the effect of the reform on children's living arrangements during the benefit take-up period. We pool observations from the first and second year of a child's life (see Table 1), which gives in total 9,889 children. $^{15}$

Since the new parental leave benefits depend on the pre-birth earnings of the parent who interrupts employment, i.e., usually the mother, we use the maternal pre-birth employment status to categorize whether a mother belongs to the group of reform winners (with pre-birth employment) or losers (without pre-birth employment). We classify mothers as winners if they had done any paid work during the twelve months prior to giving birth. Benefit take-up statistics support this classification as mothers with any pre-birth employment receive on average more than twice the benefit amount compared to mothers without any pre-birth employment: in 2011,

14 The most striking are probably the substantial differences in marriage rates and out-off wedlock childbearing. For example, in 2012, 62 percent of births in East Germany were out-off wedlock, compared to 28 percent in West Germany (STBA 2014). In addition, Bauernschuster and Rainer (2012) show vast and even increasing differences in sex-role attitudes between East and West Germany. Kreyenfeld and Geisler (2006) discuss that the two regions differ substantially with regard to attitudes towards cohabitation and maternal labor force participation. Schnabel (2016) demonstrates that East and West German women differ also in their labor supply, both in terms of participation and work hours.

15 These numbers exclude 0.6 percent of children with inconsistent information on living arrangements. Specifically, the data report that the children live with a single mother, but characterize a child's father as also living in this household. Our results are robust to inclusion of the implausible observations. 
the average benefits for the two groups amounted to 868 and 330 EUR, respectively (STBA 2013). Clearly, mothers who did not work prior to childbirth are worse-off after the reform: their average benefit of 330 EUR is only 10 percent higher than the previous payment and it is now paid out for 12 as opposed to 24 months. Conversely, the gains for working mothers, either from new eligibility or increased benefit payments, will outweigh the losses incurred by the shortened benefit period. Thus, the share of losers is higher among the non-working and the share of winners is higher among the group of working mothers. We adopt this definition for the remainder of the paper.

Our three dichotomous dependent variables indicate whether a child lives with a married couple, a cohabiting couple, or a single mother at the time of the interview. We present descriptive statistics on the dependent and independent variables in Table 2 for the total sample and separately for the group of reform winners and losers. Overall, Panel A reveals pronounced differences in living arrangements between the two groups: children of reform losers are almost twice as likely to live with a single mother (17.7 versus 9.3 percent), and 8.4 percentage points less likely to live with married parents than children of reform winners. Panel B shows that differences in the characteristics of the children are fairly small in magnitude. Panel $\mathrm{C}$ reveals substantial differences in maternal characteristics as mothers who lost out from the reform give birth at younger ages, have lower levels of education and lower levels of occupational degrees. These maternal differences support our categorization into reform winners and losers.

\section{RESUlTs}

We start out by inspecting the graphical evidence: Figure 3 describes the development of the three analyzed living arrangements over time. The x-axis shows the month of a child's birth relative to the reform's introduction, so that zero corresponds to January 2007. Each dot displays the mean probability of being observed in a particular living arrangement in the first two years of life for sampled children born in a specific month. To relate the overall 
development to the reform's introduction, we fit separate linear trends for the periods before and after the cut-off date.

The upper plot shows that the probability of living with a married couple has continuously decreased over time. We do not observe a substantial change in the trend at the time of the reform. In contrast, the middle plot depicts a significant jump in the probability of living with a cohabiting couple after the reform. Importantly, the graph suggests that the reform shifted the trend in the cohabitation outcomes permanently and not only in the short run wake of the reform. Finally, the bottom plot reveals that the probability of single motherhood was increasing before the reform but then suddenly decreased. Here, the discontinuity in the trend is statistically not significant.

Next, we turn to our estimation results: Table 3 reports our key results on the effect of the parental leave reform on child living arrangements in their first two years of life (ages 0-1). Each cell shows the estimated coefficient $\gamma$ obtained from a separate linear probability model and its robust standard error. The mutually exclusive outcome measures in columns 1 to 3 are indicator variables of whether a child lives with a married couple, with a cohabiting couple, or with a single mother, respectively. We first estimate the effects on the entire sample (panel A) and then separately for children of reform winners and losers (panels B and C). ${ }^{16}$

The results in panel A show that the reform significantly increased the probability of living with cohabiting parents in early childhood by 3.8 percentage points (column 2 ). This is a quantitatively large effect given the average incidence of roughly 16 percent before the

16 The number of observations in panels B and C do not sum up to the full sample size because we do not observe mother's employment status for about 4 percent of sampled children. However, for all tables included in the paper, we repeated the estimations for panel A after excluding the observations with missing information on mother's employment, and the results remained unchanged. 
reform. ${ }^{17}$ Interestingly, both alternative living arrangements contribute in similar magnitudes to the increase in cohabitation, where the estimates are statistically insignificant.

Panel B evaluates the reform effect for children whose mothers lost out from the reform. The point estimates in columns 1 and 2 suggest a shift away from marriage towards cohabitation, but the effects are not statistically significant. The effect on the probability of living with a single mother is close to zero. In contrast, panel $\mathrm{C}$ demonstrates that the reform significantly affected living arrangements of children whose mothers gained from the reform. The statistically and economically significant effects in columns 2 and 3 show that the probability of parental cohabitation increased by 4.3 percentage points which results largely from a reduced incidence of single motherhood among reform winners. We do not find any notable shift away from marital unions (column 1).

Overall, the estimates in Table 3 show that the parental leave reform increased the probability that a child lives with cohabiting parents in the first two years of life. This goes along with a reduced incidence of single motherhood among the potential winners of the reform. Appendix Table A.2 presents the estimation results for the samples of older children (aged 23). The estimates show that the positive effects on the probability of being raised by both parents persist at ages 2-3 as the probability of being raised by a single mother decreases by 4.4 percentage points.

How do these results relate to the mechanisms behind the changes in living arrangements discussed in Section 3? First, considering the economic independence hypothesis, we do not find the hypothesized increase in single motherhood among winners of the reform. The point estimates for children of reform winners suggest rather the contrary, i.e., a reduction

17 Note that such large reform effects are not uncommon, as Bitler et al. (2006), for instance, find that waivers reduced the probability of living with unmarried parents by 14.4 percent, and even doubled the probability of living with neither parent in some groups. 
in single motherhood accompanied by a shift from married unions towards cohabitation. Thus, our study provides new evidence rejecting the economic independence hypothesis.

As discussed in Section 3, the significant shift away from single motherhood towards cohabitation is consistent with a number of mechanisms, in particular the increase in women's relative financial attractiveness, bargaining power within a cooperative household model, and household welfare; all these mechanisms are expected to decrease the incidence of single motherhood for the winners of the reform. Moreover, we hypothesized that the risk of being raised by a single mother should only decline for children of reform winners, i.e., children of working mothers. In this case, the fathers are not the only income earners and can potentially afford to reduce labor supply to take up parental leave. Matching the hypothesized patterns, we indeed observe a reduced incidence of single motherhood only amongst the group of reform winners and not amongst the group of reform losers. This change for reform winners is consistent with the father involvement hypothesis which suggests that higher paternal leave taking strengthens the father-child attachment and results in lower incidences of single motherhood.

For children of reform losers, we do not observe any changes in the probability of living with a single mother but rather a shift away from married to cohabiting parents. The lack of an effect on single motherhood is at odds with our hypotheses regarding time limits and reductions in women's bargaining power, relative financial attractiveness, and household welfare. These mechanisms rather predict decreases in single motherhood. The insignificant shift away from marital unions towards cohabitation may reflect a loss in women's bargaining power since marriage in Germany provides stronger financial and legal security for women than cohabitation. Moreover, this shift is broadly consistent with the tax disincentives; we test this hypothesis in more detail later.

To investigate gender differences, we perform additional estimations which include an interaction term between the reform effect and the gender of the child. Table 4 reports the 
results. The first row in each panel evaluates the reform effect for girls. The second row shows whether significant differences exist between boys and girls. Table 4 largely underpins our main result that the reform decreases the risk of growing up in a single mother household (see column 3). Again, the effect is much stronger for families who gained from the reform (panel C). Moreover, we find that these positive incentives are particularly pronounced for newborn daughters. The absolute reform effects for sons derive from summing up the reported point estimates in the first and second row in each panel. We find that the reform has no effect on the probability that fathers live with a single mother for boys.

A crucial question from a policy perspective is whether the reform balances a prior disadvantage in paternal involvement experienced by girls, or whether the reform generates new gender-specific early childhood inequalities in Germany. To examine the issue, we estimate the probability for sons and daughters to live in either type of household composition. We run linear probability models for the living arrangements separately for births prior to the reform (2005-2006) and after the reform (2007-2012) including children born in all quarters of the survey years.

Table 5 reports the estimates of the boy indicator which characterizes overall gender differences: the results in Panel A expose significant gender differences in child living arrangements prior to the reform. Consistent with evidence for the US (Dahl and Moretti 2008), we observe significantly higher probabilities for sons to live with married parents, no significant gender difference regarding cohabitation, and a significantly higher propensity for daughters to live with single mothers. This suggests that prior to the reform fathers sorted into households with sons. The results in Panel B show that the differences disappear after the reform. Overall, 
Tables 4 and 5 suggest that the reform contributed to balance prior disadvantages of daughters compared to sons. ${ }^{18}$

These observed patterns might appear at odds with the literature suggesting that boys should primarily benefit from greater paternal involvements if fathers prefer sons over daughters. We rationalize the observed patterns borrowing terms from the treatment effects literature: fathers may be always-takers when it comes to paternal involvement in the rearing of sons, i.e., fathers will always spend time with their sons irrespective of the parental leave system. However, for girls, fathers may be compliers: some fathers may not have taken the time to get involved with their daughters pre-reform, but do so post-reform when they newly take parental leave. Our findings are consistent with the interpretation that higher paternal leave taking after the reform benefits girls in particular, what we call a "complier-effect", given that fathers will always get involved in the rearing of their sons likely due to social norms.

With respect to the tax effects of the reform, Table 3 yields weak evidence that couples respond to the new short-term tax disadvantage of marriage: while the propensity of cohabitation increased as expected, it is not clear whether this change results from reduced marriage rates. As the progressivity effect is particularly large at household incomes below the median where average tax rates increase the most for a given shift in income (see Table A.1 and Figure 2), we investigate our hypothesis further and consider households grouped by the level of their income. We split the sample based on annual household income at the median, i.e., around 40,000 Euros. ${ }^{19}$ If couples respond to the new tax disadvantages, then families below the median should display lower marriage probabilities, compared to couples above the median (see Table A.1 column 4). Table 6 presents the results on the propensity to marry for a

\footnotetext{
18 We also examined the sensitivity of the results in Table 4 with respect to gender-specific time trends by including additional interaction terms between the child's gender and the cohort indicator variables. The main results do not change.

19 The result remains robust when we use a much lower cut-off value of 20,000 Euros instead.
} 
sample of couples, only; we interact the reform effect with an indicator for whether a couple is above median income. We do not find a significant drop in marriage rates for families below median income; furthermore, none of the interaction terms are statistically significant. ${ }^{20}$ Overall, we find no support for the hypothesis that the reform disincentivizes marriage during the period of transfer receipt.

\section{ROBUSTNESS TESTS}

In this section, we examine the robustness of our results with respect to a number of potential concerns. We estimate our models without any control variables to assess the importance of potentially confounding factors. Next, we vary the composition of the control groups to check whether seasonal trends are stable across different control cohorts. We also exclude January and December births to assess the importance of birth shifting. We also use a larger observation window around the cut-off date and change the empirical strategy to a regression discontinuity design (RDD). This approach tests for a discontinuous change in living arrangements around January 2007 by partialling out smooth trends and seasonality in the outcomes over time. Finally, we simulate two placebo reforms taking place the year before and after the actual reform. These placebo reforms implicitly test the common trend assumption. Table 7 presents the results for the various checks separately for each group. For ease of comparison, we include the baseline coefficient in the first row within each panel.

Starting with the pooled sample in Panel A, we see that the main findings are highly robust. Model A2 shows that the effect does not depend on controlling for characteristics of the child or the mother at birth, confirming that the reform was unanticipated and hence uncorrelated with observable characteristics. In specifications A3 and A4, we vary the time

$20 \quad$ Kluve and Schmitz (2014) who pool East and West Germany report significant negative effects on marriage rates. When we add the East German observations, our estimates are very close to theirs. This underscores the heterogeneity between the two regions of the country. 
window of the reform to test whether our selection of the control group affects the results. Our main conclusions do not change. To assess whether couples anticipated the reform by changing the birth date, we drop January and December births as in specification A5. The results are less precisely estimated but the qualitative patterns remain the same. In specification A6 we use six instead of three months of observations around the cut-off date: the point estimates are nearly identical. Next, we turn to our alternative identification approach - RDD - by estimating

$$
\mathrm{y}_{i}=\text { const }+\alpha \text { post }_{\mathrm{i}}+\Phi\left(\mathrm{m}_{i}\right)+\operatorname{mob}_{\mathrm{i}}^{\prime} \theta+\mathrm{x}_{\mathrm{i}}^{\prime} \delta+\varepsilon_{i}
$$

where post $_{i}$ is an indicator for the post-reform period, $\Phi\left(\mathrm{m}_{\mathrm{i}}\right)$ denotes a function of the running variable of month of birth, and $m o b_{i}$ includes eleven dummy variables for the calendar month of birth. $x_{i}$ indicates covariates as before. In separate regressions, we use linear (A7), quadratic (A8), and cubic (A9) specifications for $\Phi$. The RDD estimations are more precise because the sample is not limited to children born up to three months around the cutoff. The estimates lead to the same conclusions as our initial difference-in-differences strategy.

Finally, we simulate two placebo reforms in the year before (A10) and after the reform (A11). ${ }^{21}$ As expected, the results for the placebo tests are insignificant lending credibility to the common trend assumption and confirming our main conclusions.

Panel B focuses on the small subsample of mothers who lost out from the reform; given the small number of treated individuals in each group, the validity of the test results may be limited. We find that the estimates remain robust when dropping the control variables (B2) or changing the time windows (B3, B4, and B6). However, none of the estimated effects are significantly different from zero. We obtain the same results using the alternative RDD identification strategy (B7-B9). Although the coefficients flip sign once we exclude the January and December births (B5), the estimates are again not statistically significant. However, we

21 We drop the reform cohort from the placebo estimations because it would otherwise as an element of the control group - bias the estimates. 
place some caution on the interpretation of the results for this group given the lack of precision and a significant placebo effect for the year 2005/06 (B11).

Comparing the coefficients across rows for the potential winners of the reform in Panel $\mathrm{C}$, we see that the estimated effects are highly robust to the various specification checks. In particular, changing the control variables (C2) and time windows (C3-C6) does not change the main conclusions. Omitting December and January births (see C5) even increases the magnitude of our point estimates. The RDD approach and especially the most flexible cubic specification (C9) also support our main conclusions. As expected, the two placebo reforms (C10-C11) yield insignificant results lending credibility to the common trend assumption. ${ }^{22}$

Overall, we conclude that our main results, particularly for the group of reform winners, are robust to changes in the control variables, control groups, estimation strategy, and estimation window sizes.

\section{CONCLUSIONS}

We study the causal effect of a recent paid parental leave reform on children's living arrangements in Germany. A large literature documents the relevance of living arrangements for the wellbeing and long run outcomes of children and discusses the relevance of public policies for these patterns. The German reform replaced a rather small means-tested benefit (Erziehungsgeld) available for a subgroup of parents with a universal paid parental leave benefit (Elterngeld) based on prior labor income. Losers of the reform lost at least 22 percent of their net household income, while winners gained up to 33 percent. To identify the causal effect of the reform, we use a difference-in-differences approach. The empirical analysis applies data from the German Micro Census, a large and representative annual survey. We focus on causal

22 We also checked whether selective migration might bias the estimations, e.g., because migrants might move to Germany shortly before childbirth to become eligible for parental leave benefits. We dropped children of mothers who moved to Germany in the year of birth or the year prior to giving birth. The results remained unchanged. 
reform effects in the short run, i.e., the period of benefit receipt, but show that the effects persist after the end of the take-up period.

We hypothesize that parental responses to the introduction of the new parental leave benefit are determined by economic independence effects, by changes in relative financial attractiveness and spousal bargaining processes, by new incentives for fathers to be more involved in child rearing, and by incentives deriving from the German income tax code. In addition, a large international literature suggests that the living arrangement choices of parents may vary by the sex of the child.

We examine the probability that children live with married parents, with cohabiting parents, or with a single mother. Our results show clear causal reform effects on children's living arrangements. In particular, the propensity to live with cohabiting parents increased on average by about 4 percentage points. This effect size is substantial given that on average 16 percent of all newborns live with cohabiting parents. Graphical analyses show that the reform shifted trends in living arrangements permanently and not only in the short run wake of the reform.

We find no evidence supporting economic independence effects or responses to tax incentives. However, for the children of reform winners, we find a decline in the probability of living with single parents and an increase in the propensity to live with cohabiting parents. These findings are consistent with alternative mechanisms, e.g., higher female financial attractiveness and enhanced paternal involvement in child rearing; due to data limitations we cannot separate these effects. Among children whose mothers lost out from the reform, we find no significant effect on living arrangements. For this group, it is likely that the new incentives for paternal involvement were not sufficient to balance newly arising financial disadvantages.

Interestingly, we find clear differences in reform effects by child gender. Prior to the reform, daughters were at a significantly higher risk of living with a single mother than sons. The reform-induced shifts to cohabitation apparently contribute to balance this disadvantage as they are exclusively observed for daughters. Consistent with the graphical evidence, we show 
that fathers do not simply "move in and out" to receive the new benefit, as we find a sustained decline in single motherhood 2-3 years after the reform (-4.4 percentage points).

This study contributes to our understanding of a large public policy reform: the German reform of paid parental leave produced unintended, yet important, spill-overs for children's living arrangements. Among the 1.5 million single parent families in Germany, about 40 percent receive welfare (Achatz et al. 2013). Single parent families make up about 18 percent of all welfare recipients and in 2011 received about 5.4 billion Euro of transfers (BA 2012). If the parental leave benefit reform moved just one out of ten of these families into couple households and if these households do not require welfare, this change would roughly save 500 million Euro. This back of the envelope calculation suggests that the unintended side-effects of parental leave reforms are also fiscally relevant.

We make an important contribution to the international literature by showing that a universal public policy reform affected living arrangements. Despite this evidence, such unintended spill-over effects of family policies for child living arrangements are rarely considered in policy designs. If single motherhood indeed negatively affects child outcomes, the observed effect of paid parental leave may be beneficial for children. Other governments considering the introduction or reform of parental leave should be aware of these side-effects. Future work needs to evaluate whether the changes in children's living arrangements actually carry over onto children's human capital, e.g., their cognitive and non-cognitive skills, in the short and longer run. 


\section{REFERENCES}

Achatz, Juliane, Andreas Hirsland, Torsten Lietzmann, and Cordula Zabel (2013). Alleinerziehende Mütter im Bereich des SGB II. IAB-Forschungsbericht 8/2013, Nürnberg.

Acs, Gregory and Sandi Nelson (2004). Changes in living arrangements during the late 1990s: do welfare policies matter? Journal of Policy Analysis and Management 23(2), 273-290.

Ai, Chunrgon and Edward C. Norton (2003). Interaction terms in Logit and Probit Models, Economic Letters 80(1), 123-129.

BA (Bundesagentur für Arbeit) (2012). Analytikreport der Statistik: Analyse des Arbeitsmarktes für Alleinerziehende in Deutschland 2011, Nürnberg. http://www.gutearbeit-alleinerziehende.de/assets/documents/02-Daten\%20und\%20Fakten/Statistik Analyse_Arbeitsmarkt_Alleinerziehende_BA\%202011.pdf [last access 21 July 2016].

Bauernschuster, Stefan and Helmut Rainer (2012). Political regimes and the family: how sexrole attitudes continue to differ in reunified Germany. Journal of Population Economics 25(1), 5-27.

Becker, Gary (1991). A Treatise on the Family, Enlarged Edition. Cambridge: Harvard University Print.

Bergemann, Annette, and Regina T. Riphahn (2015). Maternal Employment Effects of Paid Parental Leave. IZA Discussion Papers 9073, Institute for the Study of Labor (IZA). Bonn.

Bitler, Marianne P., Gelbach, Jonah B., and Hilary W. Hoynes (2006). Welfare reform and children's living arrangements. Journal of Human Resources 41(1), 1-27.

Bitler, Marianne P., Gelbach, Jonah B., Hoynes, Hilary W., and Madeline Zavodny (2004). The impact of welfare reform on marriage and divorce. Demography 41(2), 213-236.

Blank, Rebecca M. (2002). Evaluating Welfare Reform in the United States. Journal of Economic Literature 40(4), 1105-66.

Blau, David M. and Wilbert van der Klaauw (2013). What determines family structure? Economic Inquiry 51(1), 579-604.

Brooks-Gunn, J., Han, W. J., \& Waldfogel, J. (2002). Maternal employment and child cognitive outcomes in the first three years of life: The NICHD study of early child care. Child Development, 73(4), 1052-1072.

Browning, Martin, Pierre-André Chiappori, and Yoram Weiss (2014). Economics of the Family. Cambridge University Press, Cambridge.

Cancian, Maria, and Daniel R. Meyer (2014). Testing the economic independence hypothesis: The effect of an exogenous increase in child support on subsequent marriage and cohabitation. Demography 51(3), 857-880.

Choi, Hyung-Jai, Jutta M. Joesch, and Shelly Lundberg (2008). Sons, daughters, wives, and the labour market outcomes of West German men. Labour Economics 15(5), 795-811.

Cools, Sara, Jon H. Fiva, and Lars J. Kirkebøen (2015). Causal effects of paternity leave on children and parents. The Scandinavian Journal of Economics 117(3), 801-828.

Dahl, Gordon B. and Enrico Moretti (2008). The demand for sons. The Review of Economic Studies 75(4), 1085-1120.

Dickert-Conlin, Stacy and Scott Hauser (2002). EITC and Marriage. National Tax Journal. 55(1), 25-40.

Diekmann, Andreas and Kurt Schmidheiny (2004). Do Parents of Girls Have a Higher Risk of Divorce? An Eighteen-Country Study. Journal of Marriage and Family 66(3), 651-660.

Dunifon, Rachel, Kathryn Hynes, and H. Elizabeth Peters (2009). State welfare policies and children's living arrangements. Social Service Review 83(3), 351-388. 
Dustmann, C. and Uta Schönberg (2012). Expansions in maternity leave coverage and children's long-term outcomes. American Economic Journal: Applied Economics 4(3), 190-224.

Ekberg, John, Eriksson, Richard, and Friebel, Guido. (2013). Parental leave-A policy evaluation of the Swedish "Daddy-Month" reform. Journal of Public Economics 97, 131-143.

Ellwood, David T. (2000). The impact of the earned income tax credit and social policy reforms on work, marriage, and living arrangements. National Tax Journal 53(4), 1063-1105.

Finlay, Keith and David Neumark. (2010). Is marriage always good for children? Evidence from families affected by incarceration. Journal of Human Resources 45(4), 1046-1088.

Fitzgerald, John M., and David C. Ribar (2004). Welfare reform and female headship. Demography 41(2), 189-212.

Geisler, Esther and Michaela Kreyenfeld (2012). How Policy Matters: Germany's Parental Leave Benefit Reform and Fathers' Behavior 1999-2009, MPIDR Working Paper WP 2012-021, Max-Planck-Institute for Demographic Research, Rostock.

Gregg, P., Harkness, S., and Sarah Smith (2009). Welfare Reform and Lone Parents in the UK. The Economic Journal 119(535), F38-F65.

Grogger, Jeffrey and Lynn A. Karoly (2005). Welfare Reform: Effects of a Decade of Change. Harvard University Press, Cambridge.

$\mathrm{Hu}, \mathrm{Wei}-Y$ in (2003). Marriage and Economic Incentives. Evidence from a Welfare Experiment, Journal of Human Resources 38(4), 942-963.

Kluve, Jochen and Sebastian Schmitz (2014). Social Norms and Mothers' Labor Market Attachment. The Medium-run Effects of Parental Benefits, Ruhr Economic Papers No. 481, RWI Essen.

Kluve, Jochen and Marcus Tamm (2013). Parental leave regulations, mothers' labor force attachment and fathers' childcare involvement: evidence from a natural experiment. Journal of Population Economics 26(3), 1-23.

Köppen, K. (2011). Marriage and Cohabitation in western Germany and France. Doctoral dissertation, University of Rostock, Rostock.

Kreyenfeld, Michaela and Esther Geisler. (2006). Müttererwerbstätigkeit in Ost- und Westdeutschland, Zeitschrift für Familienforschung 18(3), 333-360.

LaLumia, Sara, James M. Sallee, and Nicholas Turner (2015). New Evidence on Taxes and the Timing of Births, American Economic Journal: Economic Policy 7(2), 258-293.

Lang, Kevin and Jay L. Zagorsky (2001). Does Growing Up with a Parent Absent Really Hurt? Journal of Human Resources 36(2), 253-73.

Lundberg, Shelly, and Robert A. Pollak (1996). Bargaining and distribution in marriage. The Journal of Economic Perspectives. 10(4), 139-158.

Lundberg, Shelly J., Robert A. Pollak, and Terence J. Wales (1997). Do husbands and wives pool their resources? Evidence from the United Kingdom child benefit. Journal of Human Resources. 32(3), 463-480.

Lundberg, Shelly, and Robert A. Pollak (2007). The American family and family economics. The Journal of Economic Perspectives. 21(2), 3-26.

Lundberg, Shelly, Pollak, Robert A. and Jenna E. Stearns (2016). Family Inequality: Diverging Patterns in Marriage, Cohabitation, and Childbearing. NBER Working Paper 22078, NBER Cambridge, Mass.

Manser, Marilyn, and Murray Brown (1980). Marriage and household decision-making: A bargaining analysis. International Economic Review 21(1), 31-44.

McLanahan Sara and Gary Sandefur (1994). Growing Up in a Single-Parent Household: What Hurts, What Helps. Harvard University Press, Cambridge.

McLanahan, Sara, Tach, Laura, and Daniel Schneider (2013). The causal effects of father absence. Annual Review of Sociology 39(1), 399-427. 
Morgan, S. Philip, Lye, Diane N., and Gretchen A. Condran (1988). Sons, daughters, and the risk of marital disruption. American Journal of Sociology 94(1), 110-129.

Neugart, Michael and Henry Ohlsson (2012). Economic incentives and the timing of births: evidence from the German parental benefit reform of 2007. Journal of Population Economics 26(1), 87-108.

Painter, Gary, and David I. Levine (2000). Family Structure and Youths' Outcomes: Which Correlations are Causal? Journal of Human Resources 35(3), 524-49.

Reich, Nora (2011). Predictors of fathers' use of parental leave in Germany. Population Review $50(2), 1-22$.

Ratcliffe, Caroline, McKernan, Signe-Mary, and Emily Rosenberg (2002). Welfare reform, living arrangements, and economic well-being: A synthesis of literature, mimeo, The Urban Institute, Washington D.C.

Rege, Mari, and Ingeborg F. Solli. (2013). The impact of paternity leave on fathers' future earnings. Demography 50(6), 2255-2277.

Schnabel, Claus. (2016). United, Yet Apart? A Note on Persistent Labour Market Differences between Western and Eastern Germany. Journal of Economics and Statistics (Jahrbücher für Nationalökonomie und Statistik) 236(2), 157-179.

Schoeni, Robert F., and Rebecca M. Blank (2000). What has welfare reform accomplished? Impacts on welfare participation, employment, income, poverty, and family structure. NBER Working Paper 7627, NBER Cambridge, Mass.

Stephan, Gesine, and Barbara Hofmann (2015). Abgänge aus Beschäftigung und Zugänge in den Leistungsbezug: Kurzfristige Effekte einer veränderten Rahmenfrist und/oder Anwartschaftszeit. IAB Aktuelle Berichte 10/2015, Nürnberg

STBA (Statistisches Bundesamt) (2008). Öffentliche Sozialleistungen. Statistik zum Elterngeld für Geburten 2007, Wiesbaden.

STBA (Statistisches Bundesamt) (2012). Pressekonferenz "Elterngeld - Wer, wie lange und wie viel?" am 27. Juni 2012 in Berlin. Statement von Präsident Rodrich Egeler, Wiesbaden.

STBA (Statistisches Bundesamt) (2013). Öffentliche Sozialleistungen. Statistik zum Elterngeld - Beendete Leistungsbezüge für im Jahr 2011 geborene Kinder, Wiesbaden.

STBA (Statistisches Bundesamt) (2014). Bevölkerung und Erwerbstätigkeit. Natürliche Bevölkerungsbewegung 2012, Wiesbaden.

STBA (Statistisches Bundesamt) (2015a). Öffentliche Sozialleistungen. Statistik zum Elterngeld. Beendete Leistungsbezüge für im 3. Vierteljahr 2013 geborene Kinder. Wiesbaden.

STBA (Statistisches Bundesamt) (2015b). Öffentliche Sozialleistungen. Statistik zum Elterngeld. Beendete Leistungsbezüge für im Jahr 2013 geborene Kinder. Wiesbaden.

STBA (Statistisches Bundesamt) (2016). Mikrozensus 2015. Qualitätsbericht, Wiesbaden. https://www.destatis.de/DE/Publikationen/Qualitaetsberichte/Bevoelkerung/Mikrozens us2015.pdf?_blob=publicationFile [last access Nov. 17, 2016]

Tamm, Marcus (2012). The impact of a large parental leave benefit reform on the timing of birth around the day of implementation. Oxford Bulletin of Economics and Statistics 75(4), 1-17. 
Figure 1. Share of births with paternal receipt of parental leave benefit by quarter of birth

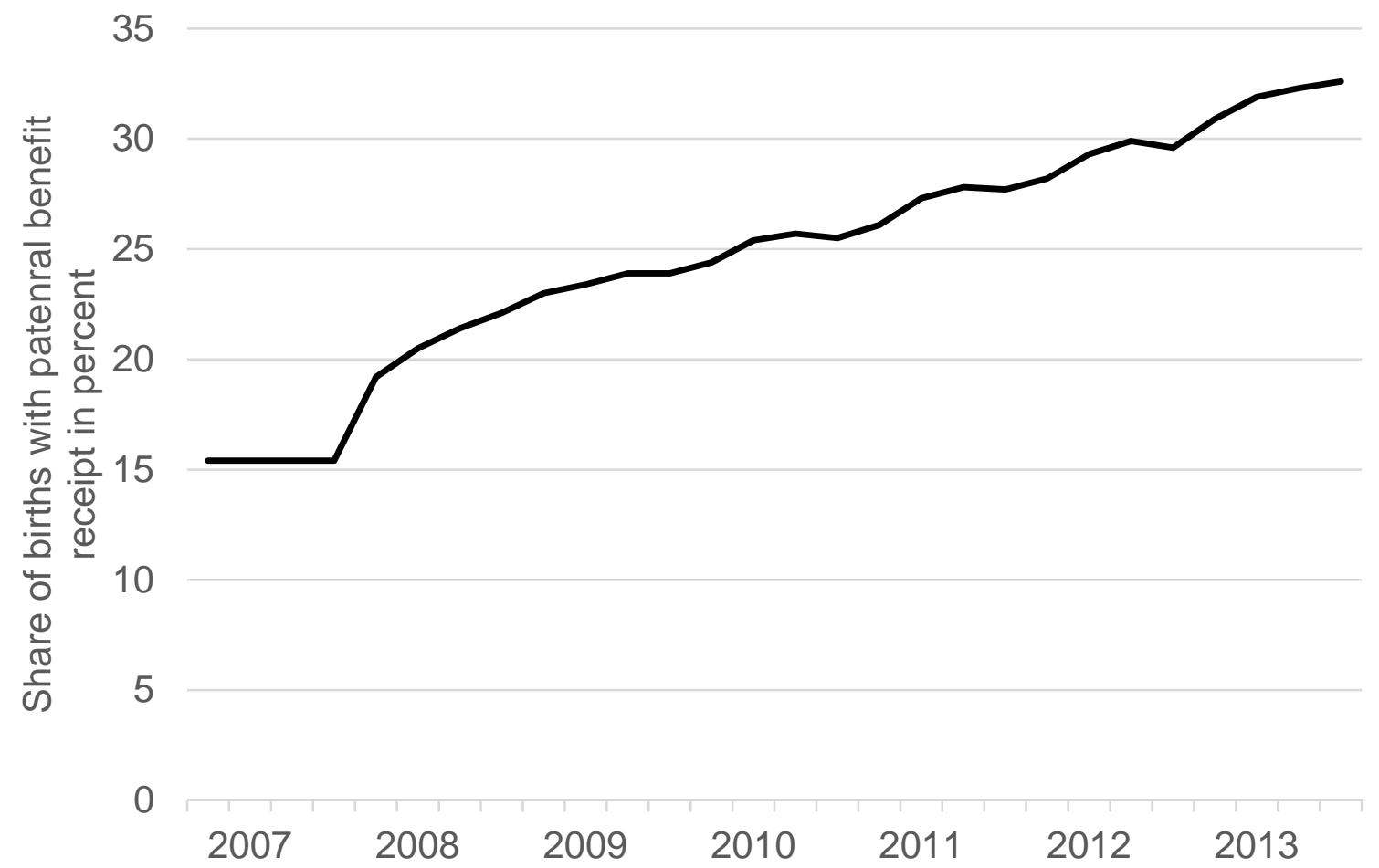

Source: For 2007 births, we only have information for the full year (see STBA 2008); STBA (2015) provide quarterly information for births from Q1 2008 through Q4 2013. 
Figure 2. Average income tax rate, by household income

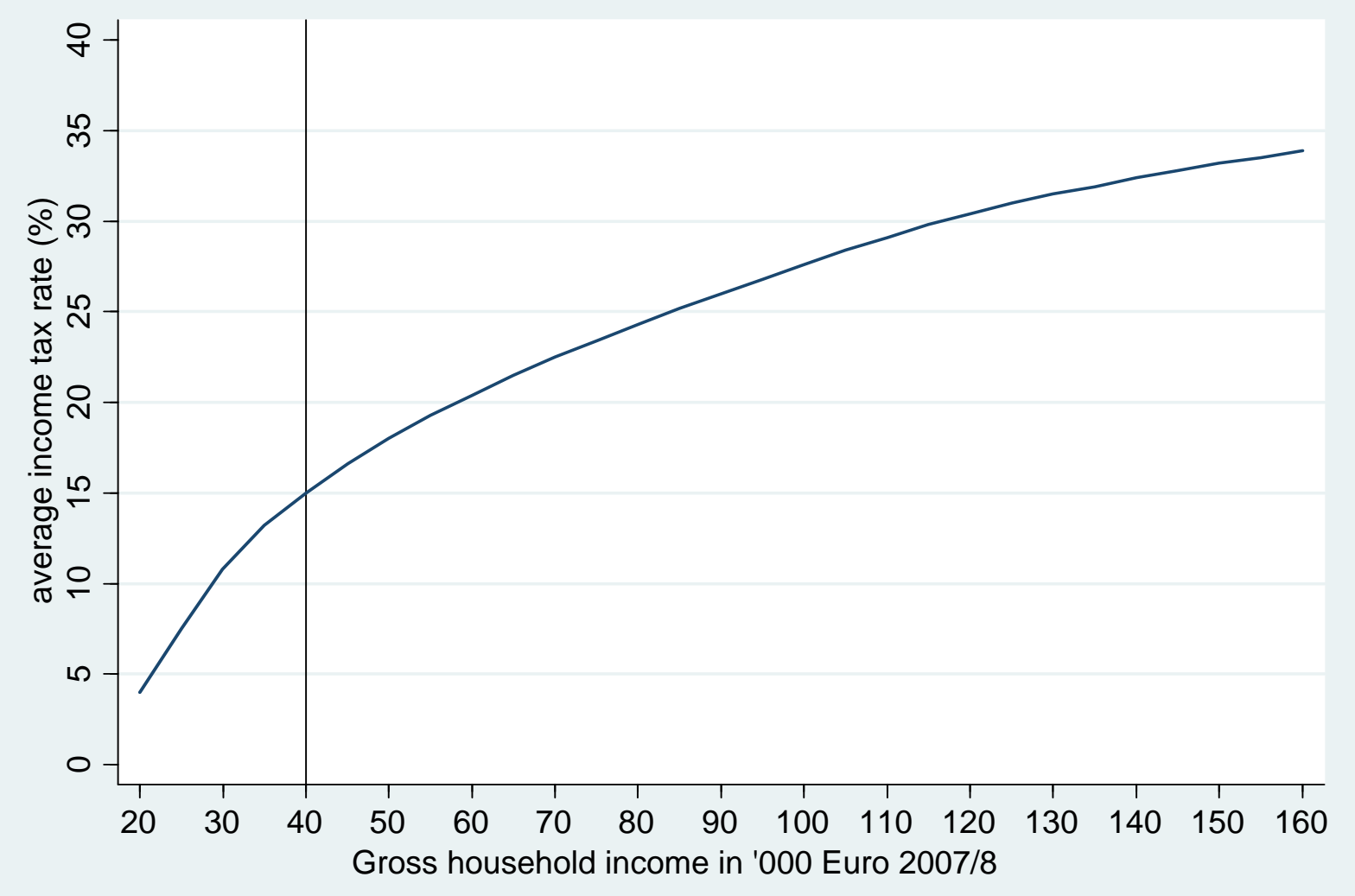

Note: The bar at 40,000 Euro indicates the median gross household income in our sample of married couples. The median gross annual household income is approximated based on information on monthly net household incomes from the Micro Census. 
Figure 3. Development of children's living arrangements over time
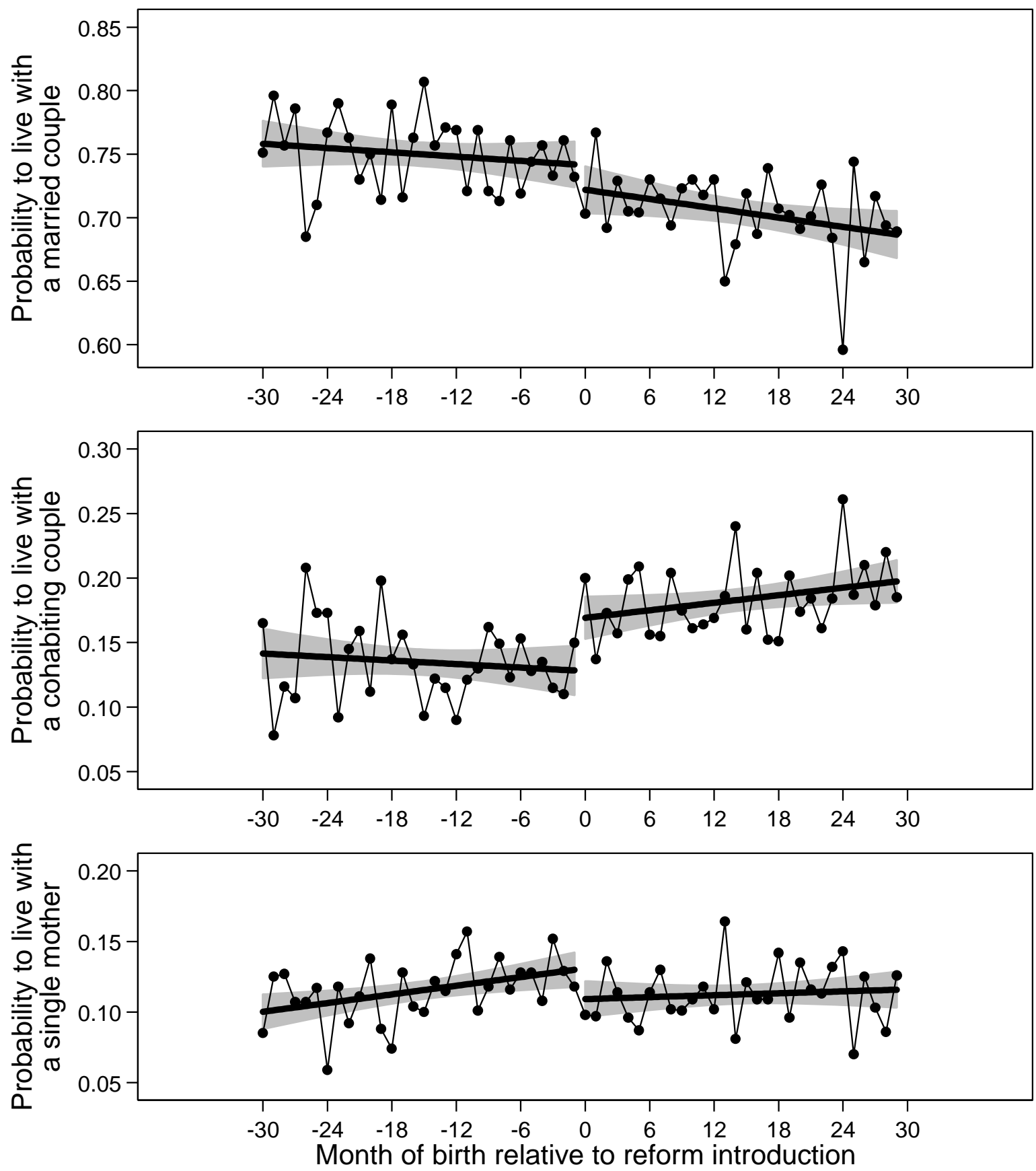

Note: The zero on the $\mathrm{x}$-axis corresponds to January 2007. The dots show monthly means in outcomes. The solid lines represent linear trends and the shaded areas the 90 percent confidence intervals around the fits for the periods before and after the reform.

Source: Micro Census survey years 2005-2012, own calculations. Samples restricted to firstborn children who were born in Germany and reside in West Germany. 
Table 1. Sample construction: number of observations by survey year and birth cohort

\begin{tabular}{|l|cccccccc|}
\hline & \multicolumn{7}{|c|}{ Micro Census survey year } \\
Birth cohort & 2005 & 2006 & 2007 & 2008 & 2009 & 2010 & 2011 & 2012 \\
\hline $2004 / 5$ & 965 & 1,091 & 1,077 & 1,088 & 0 & 0 & 0 & 0 \\
$2005 / 6$ & 0 & 956 & 1,006 & 1,006 & 1,010 & 0 & 0 & 0 \\
$2006 / 7=$ treated & 0 & 0 & 906 & 1,001 & 980 & 1,011 & 0 & 0 \\
$2007 / 8$ & 0 & 0 & 0 & 1,004 & 1,085 & 1,034 & 1,009 & 0 \\
$2008 / 9$ & 0 & 0 & 0 & 0 & 907 & 968 & 1,010 & 975 \\
\hline
\end{tabular}

Notes: the colors refer to the year of a child's life (age) at the time of the survey

$$
\begin{array}{llll}
\text { 1st } & \text { 2nd } & \text { 3rd } & \text { 4th } \\
\text { (age 0) } & \text { (age 1) } & \text { (age 2) } & \text { (age 3) }
\end{array}
$$

Source: Micro Census survey years 2005-2012, own calculations. Samples restricted to firstborn children who were born in Germany and reside in West Germany. Each entry counts the observations within the three months before and after the change of the year. 
Table 2. Descriptive Statistics

\begin{tabular}{|c|c|c|c|c|c|c|c|}
\hline & \multicolumn{2}{|c|}{ all } & \multicolumn{4}{|c|}{ "Reform winners" "Reform losers" } & \multirow[b]{2}{*}{ Diff. } \\
\hline & Mean & St.Dev. & Mean & St.Dev. & Mean & St.Dev. & \\
\hline \multicolumn{8}{|l|}{\begin{tabular}{|l|} 
A. Child's living arrangement \\
\end{tabular}} \\
\hline married couple & 0.728 & 0.445 & 0.751 & 0.433 & 0.667 & 0.471 & $0.084 * * *$ \\
\hline cohabiting couple & 0.158 & 0.364 & 0.157 & 0.364 & 0.156 & 0.362 & 0.001 \\
\hline single mother & 0.114 & 0.318 & 0.093 & 0.290 & 0.177 & 0.382 & $-0.084 * * *$ \\
\hline \multicolumn{8}{|l|}{ B. Child's characteristics } \\
\hline birth cohort 200 & 0.190 & 0.392 & 0.194 & 0.395 & 0.174 & 0.379 & $0.020^{* *}$ \\
\hline birth cohort 2007/08 & 0.211 & 0.408 & 0.214 & 0.410 & 0.195 & 0.396 & $0.019^{*}$ \\
\hline birth cohort 2006/07 (treated) & 0.193 & 0.395 & 0.189 & 0.391 & 0.212 & 0.409 & $-0.023 * *$ \\
\hline birth cohort 2005/06 & 0.198 & 0.399 & 0.200 & 0.400 & 0.198 & 0.398 & 0.002 \\
\hline birth cohort 2004/05 & 0.208 & 0.406 & 0.203 & 0.402 & 0.221 & 0.415 & $-0.018 *$ \\
\hline born in 1st quarter of year & 0.486 & 0.500 & 0.491 & 0.500 & 0.470 & 0.499 & $0.021^{*}$ \\
\hline male & 0.497 & 0.500 & 0.499 & 0.500 & 0.495 & 0.500 & 0.004 \\
\hline multiple birth & 0.036 & 0.187 & 0.039 & 0.194 & 0.029 & 0.167 & $0.010 * *$ \\
\hline age in months & 13.720 & 6.850 & 13.298 & 6.809 & 14.970 & 6.752 & $-1.672 * * *$ \\
\hline \multicolumn{8}{|l|}{ C. Maternal characteristics } \\
\hline age a & 28.753 & 5.523 & 29.593 & 5.191 & 25.953 & 5.689 & $3.640 * * *$ \\
\hline school degree: no & 0.030 & 0.170 & 0.010 & 0.097 & 0.095 & 0.293 & $-0.085 * * *$ \\
\hline school degree: Haup & 0.221 & 0.415 & 0.189 & 0.391 & 0.315 & 0.464 & $-0.126 * * *$ \\
\hline school degree: Realschulabschluss & 0.354 & 0.478 & 0.384 & 0.487 & 0.263 & 0.440 & $0.121 * * *$ \\
\hline school degree: Fachhochschulreife & 0.082 & 0.275 & 0.089 & 0.284 & 0.063 & 0.243 & $0.026 * * *$ \\
\hline egree: Abitur & 0.300 & 0.458 & 0.321 & 0.467 & 0.241 & 0.428 & $0.080 * * *$ \\
\hline school degree: other & 0.004 & 0.064 & 0.003 & 0.054 & 0.008 & 0.089 & $-0.005 * * *$ \\
\hline school degree: missing & 0.008 & 0.090 & 0.005 & 0.070 & 0.016 & 0.126 & $-0.011 * * *$ \\
\hline occupational degree: no & 0.205 & 0.404 & 0.114 & 0.317 & 0.496 & 0.500 & $-0.382 * * *$ \\
\hline occupational degree: blue c & 0.511 & 0.500 & 0.577 & 0.494 & 0.303 & 0.460 & $0.274 * * *$ \\
\hline occupational degree: white collar & 0.090 & 0.287 & 0.101 & 0.301 & 0.054 & 0.226 & $0.047 * * *$ \\
\hline occupational degree: tertiary degree & 0.179 & 0.383 & 0.197 & 0.397 & 0.130 & 0.336 & $0.067 * * *$ \\
\hline occupational degree: other & 0.010 & 0.100 & 0.009 & 0.095 & 0.010 & 0.101 & -0.001 \\
\hline occupational degree: missing & 0.004 & 0.066 & 0.003 & 0.054 & 0.007 & 0.084 & $-0.004 * * *$ \\
\hline pre-birth employment: & 0.226 & 0.418 & - & - & - & - & - \\
\hline pre-birth employment: working & 0.739 & 0.439 & - & - & - & - & - \\
\hline pre-birth employment: missing & 0.036 & 0.185 & - & - & - & - & - \\
\hline \multirow{2}{*}{\begin{tabular}{|l} 
born in Germa1 \\
Observations
\end{tabular}} & 0.782 & 0.413 & 0.842 & 0.365 & 0.594 & 0.491 & $0.248 * * *$ \\
\hline & \multicolumn{2}{|c|}{9,889} & \multicolumn{2}{|c|}{7,306} & \multicolumn{2}{|c|}{2,2} & \\
\hline
\end{tabular}

Source: Micro Census survey years 2005-2010, own calculations. Federal state indicators not shown to save space. Samples are restricted to first-born children who were born in Germany and reside in West Germany. We define reform losers (winners) as children of non-working (working) mothers in the last 12 months prior to giving birth. Diff. stands for the difference in the means for the reform "winners" and "losers". *, **, and *** indicate statistical significance of this difference at the 10,5 , and 1 percent level. 
Table 3. Estimation results: effects on children's living arrangements (at ages 0-1)

\begin{tabular}{|lrrr|} 
& $\begin{array}{r}(1) \\
\text { married } \\
\text { couple }\end{array}$ & $\begin{array}{r}(2) \\
\text { cohabiting } \\
\text { couple }\end{array}$ & $\begin{array}{r}(3) \\
\text { single } \\
\text { mother }\end{array}$ \\
\hline $\begin{array}{l}\text { Panel A: all children }(\mathrm{N}=9,889) \\
\text { treat*after }\end{array}$ & -0.018 & $0.038 * *$ & -0.021 \\
& $(0.021)$ & $(0.018)$ & $(0.016)$ \\
Mean dependent variable & 0.728 & 0.158 & 0.114 \\
\hline Panel B: "reform losers" (N=2,231) & & & \\
treat*after & -0.038 & 0.032 & 0.006 \\
& $(0.043)$ & $(0.034)$ & $(0.038)$ \\
Mean dependent variable & 0.667 & 0.156 & 0.177 \\
\hline Panel C: "reform winners" (N=7,306) & & & \\
treat*after & -0.012 & $0.043 * *$ & $-0.031 *$ \\
& $(0.025)$ & $(0.021)$ & $(0.017)$ \\
Mean dependent variable & 0.750 & 0.157 & 0.093 \\
\hline Child characteristics & yes & yes & yes \\
Maternal characteristics at childbirth & yes & yes & yes \\
\hline
\end{tabular}

Notes: Each cell represents a separate linear regression. All regressions include a constant. Child characteristics comprise indicators for a child's birth cohort, quarter of birth, gender, multiple birth, and state of residence, as well as age in months (linear and squared). Maternal characteristics at childbirth include a mother's age in years (linear and squared), indicators for education, pre-birth employment status, and migration status. We define reform losers (winners) as children of non-working (working) mothers in the last 12 months prior to giving birth. Robust standard errors in parentheses. ${ }^{*}, * *$, and $* * *$ indicate statistical significance at the 10,5 , and 1 percent level.

Source: Micro Census survey years 2005-2010, own calculations. Samples restricted to firstborn children who were born in Germany and reside in West Germany. 
Table 4. Estimation results: effects on children's living arrangements (at ages 0-1), by gender

\begin{tabular}{|lrr|r|}
\hline & $\begin{array}{r}(1) \\
\text { married } \\
\text { couple }\end{array}$ & $\begin{array}{r}(2) \\
\text { cohabiting } \\
\text { couple }\end{array}$ & $\begin{array}{r}(3) \\
\text { single } \\
\text { mother }\end{array}$ \\
\hline Panel A: all children $(\mathrm{N}=9,889)$ & & & \\
treat*after & 0.002 & $0.046 *$ & $-0.048 * *$ \\
& $(0.030)$ & $(0.025)$ & $(0.023)$ \\
treat*after*boy & -0.039 & -0.016 & $0.054 *$ \\
& $(0.042)$ & $(0.036)$ & $(0.032)$ \\
\hline Panel B: "reform losers" $(\mathrm{N}=2,231)$ & & & \\
treat*after & -0.039 & 0.033 & 0.006 \\
& $(0.060)$ & $(0.045)$ & $(0.054)$ \\
treat*after*boy & 0.002 & -0.002 & 0.001 \\
& $(0.086)$ & $(0.069)$ & $(0.076)$ \\
\hline Panel C: "reform winners" $(\mathrm{N}=7,306)$ & & & \\
treat*after & 0.017 & 0.048 & $-0.065 * *$ \\
& $(0.036)$ & $(0.030)$ & $(0.025)$ \\
treat*after*boy & -0.058 & -0.010 & $0.068 * *$ \\
& $(0.050)$ & $(0.043)$ & $(0.034)$ \\
\hline Child characteristics & yes & yes & yes \\
Maternal characteristics at childbirth & yes & yes & yes \\
\hline
\end{tabular}

Notes: Each column within a panel shows coefficients and standard errors from a separate linear regression. All regressions include a constant. Child's characteristics comprise indicators for a child birth cohort, quarter of birth, gender, multiple birth, and state of residence, as well as age in months (linear and squared). Maternal characteristics at childbirth include a mother's age in years (linear and squared), indicators for education, pre-birth employment status, and migration status. We define reform losers (winners) as children of non-working (working) mothers in the last 12 months prior to giving birth. ${ }^{*}, * *$, and $* * *$ indicate statistical significance at the 10,5 , and 1 percent level.

Source: Micro Census survey years 2005-2010, own calculations. Samples restricted to firstborn children who were born in Germany and reside in West Germany. 
Table 5. Estimation results: effect of child gender on children's living arrangements (at ages 0-1)

\begin{tabular}{|c|c|c|c|}
\hline & married couple & cohabiting couple & single mother \\
\hline $\begin{array}{l}\text { Panel A: Before reform (all births in } \\
\text { boy }\end{array}$ & $\begin{array}{r}005-2006 ; \mathrm{N}=12,36 \\
0.018^{* *} \\
(0.007) \\
\end{array}$ & $\begin{array}{l}-0.004 \\
(0.006) \\
\end{array}$ & $\begin{array}{l}-0.014 * * * \\
(0.006)\end{array}$ \\
\hline $\begin{array}{l}\text { Panel B: After reform (all births in } 2 \\
\text { boy }\end{array}$ & $\begin{array}{c}07-2012 ; \mathrm{N}=20,966) \\
0.008 \\
(0.006) \\
\end{array}$ & $\begin{array}{l}-0.006 \\
(0.005) \\
\end{array}$ & $\begin{array}{l}-0.001 \\
(0.004)\end{array}$ \\
\hline Child characteristics & yes & yes & yes \\
\hline Maternal characteristics at childbirth & yes & yes & yes \\
\hline
\end{tabular}

Notes: Each cell represents a separate linear regression. Only child observations with both parents in the household are considered. All regressions include a constant and controls for child and maternal characteristics. Child characteristics comprise indicators for a child's birth cohort, quarter of birth, gender, multiple birth, and state of residence, as well as age in months (linear and squared). Maternal characteristics at childbirth include a mother's age in years (linear and squared), indicators for education, pre-birth employment status, and migration status. A mother's working status refers to her status in the last 12 pre-birth months. Robust standard errors in parentheses. $* * *$, and $* * *$ indicate statistical significance at the 10,5 , and 1 percent level.

Source: Micro Census survey years 2005-2012, own calculations. Samples restricted to firstborn children who were born in Germany and reside in West Germany and reside with both parents. 
Table 6. Estimation results: effect heterogeneity by pre-reform income level on the propensity to have married (vs. cohabiting) parents

\begin{tabular}{|lr|}
\hline & married couple \\
\hline $\begin{array}{l}\text { Panel A: all children (N=8,001) } \\
\text { treat*after }\end{array}$ & -0.050 \\
treat*after*(above median household income) & $(0.033)$ \\
& 0.017 \\
\hline Panel B: "reform losers" (N=1,663) & $(0.042)$ \\
treat*after & -0.059 \\
& $(0.053)$ \\
treat*after*(above median household income) & 0.029 \\
& $(0.086)$ \\
\hline Panel C: "reform winners" (N=6,092) & -0.040 \\
treat*after & $(0.043)$ \\
treat*after*(above median household income) & 0.001 \\
& $(0.052)$ \\
\hline Child's characteristics & yes \\
Maternal characteristics at childbirth & yes \\
\hline
\end{tabular}

Notes: Each cell represents a separate linear regression. Only child observations with both parents in the household are considered. All regressions include a constant and controls for the interaction of "after" with the two comparative education indicators. Child characteristics comprise indicators for a child's birth cohort, quarter of birth, gender, multiple birth, and state of residence, as well as age in months (linear and squared). Maternal characteristics at childbirth include a mother's age in years (linear and squared), indicators for education, pre-birth employment status, and migration status. We define reform losers (winners) as children of nonworking (working) mothers in the last 12 months prior to giving birth. Robust standard errors in parentheses. ${ }^{*}, * *$, and $* * *$ indicate statistical significance at the 10, 5, and 1 percent level.

Source: Micro Census survey years 2005-2010, own calculations. Samples restricted to firstborn children who were born in Germany and reside in West Germany and reside with both parents. 
Table 7. Robustness checks

\begin{tabular}{|c|c|c|c|c|c|}
\hline & $\begin{array}{r}\text { married } \\
\text { couple }\end{array}$ & $\begin{array}{r}\text { cohabiting } \\
\text { couple }\end{array}$ & & $\begin{array}{l}\text { single } \\
\text { mother }\end{array}$ & \\
\hline Panel A: all children & & & & & \\
\hline A1: baseline $(\mathrm{N}=9,889)$ & -0.018 & 0.038 & $* *$ & -0.021 & \\
\hline & $(0.021)$ & $(0.018)$ & & $(0.016)$ & \\
\hline A2: no controls $(\mathrm{N}=9,889)$ & -0.013 & 0.036 & ** & -0.023 & \\
\hline & $(0.023)$ & $(0.018)$ & & $(0.017)$ & \\
\hline A3: excl. birth cohort $04 / 05$ & 0.001 & 0.026 & & -0.027 & \\
\hline$(\mathrm{N}=7,833)$ & $(0.022)$ & $(0.019)$ & & $(0.016)$ & \\
\hline A4: excl. birth cohorts $04 / 05,08 / 09$ & -0.002 & 0.034 & $*$ & -0.032 & $*$ \\
\hline$(\mathrm{N}=5,958)$ & $(0.023)$ & $(0.019)$ & & $(0.017)$ & \\
\hline A5: excl. January \& December & -0.003 & 0.030 & & -0.027 & \\
\hline$(\mathrm{N}=6,358)$ & $(0.027)$ & $(0.022)$ & & $(0.020)$ & \\
\hline A6: six-month bandwidth $(\mathrm{N}=19,631)$ & -0.012 & 0.032 & $* *$ & -0.021 & $*$ \\
\hline & $(0.015)$ & $(0.013)$ & & $(0.011)$ & \\
\hline A7: RDD linear $(\mathrm{N}=19,631)$ & -0.020 & 0.040 & $* * *$ & -0.020 & $* *$ \\
\hline & $(0.012)$ & $(0.010)$ & & $(0.009)$ & \\
\hline A8: RDD quadratic $(\mathrm{N}=19,631)$ & -0.019 & 0.039 & $* * *$ & -0.019 & $* *$ \\
\hline & $(0.012)$ & $(0.010)$ & & $(0.009)$ & \\
\hline A9: $\mathrm{RDD}$ cubic $(\mathrm{N}=19,631)$ & 0.000 & 0.037 & $* *$ & -0.037 & $* * *$ \\
\hline & $(0.017)$ & $(0.015)$ & & $(0.013)$ & \\
\hline A10: placebo reform $2007 / 8(\mathrm{~N}=7,982)$ & -0.031 & 0.021 & & 0.010 & \\
\hline & $(0.022)$ & $(0.019)$ & & $(0.015)$ & \\
\hline A11: placebo reform $2005 / 6(\mathrm{~N}=7,982)$ & -0.013 & -0.012 & & 0.025 & \\
\hline & $(0.021)$ & $(0.017)$ & & $(0.016)$ & \\
\hline Panel B: "reform losers" & & & & & \\
\hline B1: baseline $(\mathrm{N}=2,231)$ & -0.038 & 0.032 & & 0.006 & \\
\hline & $(0.043)$ & $(0.034)$ & & $(0.038)$ & \\
\hline B2: no controls $(\mathrm{N}=2,231)$ & -0.031 & 0.024 & & 0.007 & \\
\hline & $(0.049)$ & $(0.036)$ & & $(0.040)$ & \\
\hline B3: excl. cohort 04/05 $(\mathrm{N}=1,737)$ & -0.015 & 0.016 & & -0.001 & \\
\hline & $(0.045)$ & $(0.036)$ & & $(0.04)$ & \\
\hline B4: excl. cohort 04/05, 08/09 & -0.031 & 0.041 & & -0.010 & \\
\hline$(\mathrm{N}=1,349)$ & $(0.048)$ & $(0.038)$ & & $(0.043)$ & \\
\hline B5: excl. January \& December & 0.063 & -0.043 & & -0.020 & \\
\hline$(\mathrm{N}=1,434)$ & $(0.053)$ & $(0.041)$ & & $(0.049)$ & \\
\hline B6: six-month bandwidth $(\mathrm{N}=4,432)$ & 0.000 & 0.015 & & -0.015 & \\
\hline & $(0.031)$ & $(0.026)$ & & $(0.027)$ & \\
\hline B7: RDD linear $(\mathrm{N}=4,432)$ & 0.003 & 0.019 & & -0.022 & \\
\hline & $(0.025)$ & $(0.021)$ & & $(0.022)$ & \\
\hline B8: RDD quadratic $(\mathrm{N}=4,432)$ & 0.003 & 0.015 & & -0.018 & \\
\hline & $(0.025)$ & $(0.021)$ & & $(0.022)$ & \\
\hline B9: $\mathrm{RDD}$ cubic $(\mathrm{N}=4,432)$ & 0.009 & 0.021 & & -0.030 & \\
\hline & $(0.035)$ & $(0.029)$ & & $(0.031)$ & \\
\hline B10: placebo reform $2007 / 8(\mathrm{~N}=1,758)$ & -0.063 & 0.053 & & 0.009 & \\
\hline & $(0.049)$ & $(0.041)$ & & $(0.042)$ & \\
\hline B11: placebo reform $2005 / 6(\mathrm{~N}=1,758)$ & 0.043 & -0.073 & $* *$ & 0.030 & \\
\hline & $(0.045)$ & $(0.035)$ & & $(0.040)$ & \\
\hline
\end{tabular}


Table 7. Robustness checks (continued)

\begin{tabular}{|c|c|c|c|c|c|c|}
\hline & $\begin{array}{r}\text { married } \\
\text { couple }\end{array}$ & & $\begin{array}{r}\text { cohabiting } \\
\text { couple }\end{array}$ & & $\begin{array}{r}\text { single } \\
\text { mother }\end{array}$ & \\
\hline \multicolumn{7}{|l|}{ Panel C: "reform winners" } \\
\hline $\mathrm{C} 1$ : baseline $(\mathrm{N}=7,306)$ & $\begin{array}{r}-0.012 \\
(0.025)\end{array}$ & & $\begin{array}{r}0.043 \\
(0.021)\end{array}$ & ** & $\begin{array}{r}-0.031 \\
(0.017)\end{array}$ & * \\
\hline C2: no controls $(\mathrm{N}=7,306)$ & $\begin{array}{r}-0.005 \\
(0.026)\end{array}$ & & $\begin{array}{r}0.041 \\
(0.022)\end{array}$ & $*$ & $\begin{array}{r}-0.036 \\
(0.018)\end{array}$ & $* *$ \\
\hline C3: excl. cohort 04/05 $(\mathrm{N}=5,821)$ & $\begin{array}{r}0.009 \\
(0.026)\end{array}$ & & $\begin{array}{r}0.030 \\
(0.022)\end{array}$ & & $\begin{array}{r}-0.039 \\
(0.018)\end{array}$ & $* *$ \\
\hline $\begin{array}{l}\text { C4: excl. cohort 04/05, 08/09 } \\
(\mathrm{N}=4,404)\end{array}$ & $\begin{array}{r}0.006 \\
(0.027)\end{array}$ & & $\begin{array}{r}0.035 \\
(0.023)\end{array}$ & & $\begin{array}{r}-0.041 \\
(0.019)\end{array}$ & $* *$ \\
\hline $\begin{array}{l}\text { C5: excl. January \& December } \\
(\mathrm{N}=4,696)\end{array}$ & $\begin{array}{l}-0.023 \\
(0.031)\end{array}$ & & $\begin{array}{r}0.054 \\
(0.026)\end{array}$ & $* *$ & $\begin{array}{l}-0.031 \\
(0.022)\end{array}$ & \\
\hline C6: six-month bandwidth $(\mathrm{N}=14,478)$ & $\begin{array}{l}-0.014 \\
(0.018)\end{array}$ & & $\begin{array}{r}0.037 \\
(0.015)\end{array}$ & $* *$ & $\begin{array}{r}-0.023 \\
(0.012)\end{array}$ & * \\
\hline $\mathrm{C} 7$ : $\mathrm{RDD}$ linear $(\mathrm{N}=14,478)$ & $\begin{array}{r}-0.025 \\
(0.014)\end{array}$ & * & $\begin{array}{r}0.045 \\
(0.012)\end{array}$ & $* * *$ & $\begin{array}{r}-0.021 \\
(0.010)\end{array}$ & ** \\
\hline C8: RDD quadratic $(\mathrm{N}=14,478)$ & $\begin{array}{r}-0.024 \\
(0.014)\end{array}$ & * & $\begin{array}{r}0.045 \\
(0.012)\end{array}$ & $* * *$ & $\begin{array}{r}-0.020 \\
(0.010)\end{array}$ & $* *$ \\
\hline C9: $\mathrm{RDD}$ cubic $(\mathrm{N}=14,478)$ & $\begin{array}{r}-0.002 \\
(0.020)\end{array}$ & & $\begin{array}{r}0.042 \\
(0.017)\end{array}$ & $* *$ & $\begin{array}{r}-0.040 \\
(0.014)\end{array}$ & $* * *$ \\
\hline C10: placebo reform $2007 / 8(N=5,928)$ & $\begin{array}{r}-0.029 \\
(0.025)\end{array}$ & & $\begin{array}{r}0.018 \\
(0.022)\end{array}$ & & $\begin{array}{r}0.011 \\
(0.016)\end{array}$ & \\
\hline C11: placebo reform $2005 / 6(\mathrm{~N}=5,928)$ & $\begin{array}{r}-0.025 \\
(0.024)\end{array}$ & & $\begin{array}{r}-0.003 \\
(0.020)\end{array}$ & & $\begin{array}{r}0.022 \\
(0.017)\end{array}$ & \\
\hline
\end{tabular}

Notes: Each cell represents a separate linear regression. All regressions include a constant and control for child and mother's characteristics. Child characteristics comprise indicators for a child's birth cohort, quarter of birth, gender, multiple birth, and state of residence, as well as age in months (linear and squared). Maternal characteristics at childbirth include mother's age in years (linear and squared), indicators for education, pre-birth employment status, and migration status. We define reform losers (winners) as children of non-working (working) mothers in the last 12 months prior to giving birth. Robust standard errors in parentheses. *, $* *$, and $* * *$ indicate statistical significance at the 10,5, and 1 percent level. Source: Micro Census survey years 2005-2010, own calculations. Samples restricted to first-born children who were born in Germany and reside in West Germany. 


\section{ONLINE APPENDIX}

Table A.1 Average tax rates and progressivity effect

\begin{tabular}{|c|c|c|c|}
\hline $\begin{array}{c}\text { Houshold } \\
\text { income p.a. } \\
\text { (in 1,000 Euro) }\end{array}$ & $\begin{array}{c}\text { Average } \\
\text { tax rate } \\
\text { (in percent) }\end{array}$ & $\begin{array}{l}\text { Income tax } \\
\text { payable p.a. } \\
\text { (in Euro) }\end{array}$ & $\begin{array}{l}\text { Change in average } \\
\text { tax rate when income } \\
\text { plus } 5,000 \text { Euro p.a. } \\
\text { (in percentage points) }\end{array}$ \\
\hline 20 & 4 & 800 & 3.5 \\
\hline 25 & 7.5 & 1,875 & 3.3 \\
\hline 30 & 10.8 & 3,240 & 2.4 \\
\hline 35 & 13.2 & 4,620 & 1.8 \\
\hline 40 & 15.0 & 6,000 & 1.6 \\
\hline 45 & 16.6 & 7,470 & 1.4 \\
\hline 50 & 18.0 & $\quad 9,000$ & 1.3 \\
\hline 55 & 19.3 & $\quad 10,615$ & 1.1 \\
\hline 60 & 20.4 & 12,240 & 1.1 \\
\hline 65 & 21.5 & 13,975 & 1.0 \\
\hline 70 & 22.5 & 15,750 & 0.9 \\
\hline 75 & 23.4 & 17,550 & 0.9 \\
\hline 80 & 24.3 & $\quad 19,440$ & 0.9 \\
\hline 85 & 25.2 & 21,420 & 0.8 \\
\hline 90 & 26.0 & 23,400 & 0.8 \\
\hline 95 & 26.8 & 25,460 & 0.8 \\
\hline 100 & 27.6 & 27,600 & 0.8 \\
\hline 105 & 28.4 & $\quad 29,820$ & 0.7 \\
\hline 110 & 29.1 & 32,010 & 0.7 \\
\hline 115 & 29.8 & 34,270 & 0.6 \\
\hline 120 & 30.4 & $\quad 36,480$ & 0.6 \\
\hline
\end{tabular}

Note: Own calculations based on tax schedule for the fiscal year 2007. Column 4 presents the shift in average tax rates when a hypothetical parental leave benefit of 5,000 Euro is added to the household income in column 1. 
Table A.2 Estimation results: effects on children's living arrangements (at ages 2-3)

\begin{tabular}{|lrrr|}
\hline & $\begin{array}{r}(1) \\
\text { married } \\
\text { couple }\end{array}$ & $\begin{array}{r}(2) \\
\text { cohabiting } \\
\text { couple }\end{array}$ & $\begin{array}{r}(3) \\
\text { single } \\
\text { mother }\end{array}$ \\
\hline $\begin{array}{l}\text { Panel A: all children }(\mathrm{N}=10,200) \\
\text { treat*after }\end{array}$ & $\begin{array}{r}0.025 \\
(0.021)\end{array}$ & $\begin{array}{r}0.019 \\
(0.015)\end{array}$ & $-0.044 * * *$ \\
& & & $(0.017)$ \\
\hline $\begin{array}{l}\text { Panel B: "reform losers" }(\mathrm{N}=3,413) \\
\text { treat*after }\end{array}$ & -0.006 & 0.027 & -0.021 \\
& $(0.037)$ & $(0.028)$ & $(0.032)$ \\
\hline $\begin{array}{l}\text { Panel C: "reform winners" }(\mathrm{N}=5,904) \\
\text { treat*after }\end{array}$ & 0.027 & 0.017 & $-0.044 * *$ \\
& $(0.026)$ & $(0.020)$ & $(0.020)$ \\
\hline $\begin{array}{l}\text { Child's characteristics } \\
\text { Maternal characteristics at childbirth }\end{array}$ & yes & yes & yes \\
\end{tabular}

Notes: Each cell represents a separate linear regression. All regressions include a constant. Child characteristics comprise indicators for a child's birth cohort, quarter of birth, gender, multiple birth, and state of residence, as well as age in months (linear and squared). Maternal characteristics at childbirth include mother's age in years (linear and squared), indicators for education, pre-birth employment status, and migration status. We define reform losers (winners) as children of non-working (working) mothers in the last 12 months prior to giving birth. Robust standard errors in parentheses. ${ }^{*}, * *$, and $* * *$ indicate statistical significance at the 10,5 , and 1 percent level.

Source: Micro Census survey years 2007-2012, own calculations. Samples restricted to firstborn children who were born in Germany and reside in West Germany. 